\title{
Inmovilización/solidificación de residuos tóxicos y peligrosos en matrices de cemento
}

\section{Immobilisation/solidification of hazardous toxic waste in cement matrices}

\author{
A.MACÍAS,S.GOÑI,A.GUERREROYE. FERNÁNDEZ \\ Instituto de Ciencias de la Construcción Eduardo Torroja (CSIC)
}

ESPAÑA

Fecha de recepción: 9-II-99

Fecha de aceptación: 10-III-99

\section{RESUMEN}

La inmovilización y solidificación de residuos contaminantes, implantada en el sector comercial desde hace más de 20 años y que desde hace diez es objeto de creciente interés por parte de ingenieros y cientificos medioambientales, se ha convertido en un proceso estandarizado único para el tratamiento y gestión de residuos tóxicos y peligrosos líquidos y, en especial, de los que contienen metales pesados.

La monitorización experimental del comportamiento de un residuo inmovilizado por solidificación y estabilización en el tiempo de vida de un depósito de seguridad no es posible, por lo que es imprescindible desarrollar modelos que predigan satisfactoriamente el comportamiento del sistema bajo un rango representativo de condiciones del entorno de exposición. Tales modelos sólo pueden ser desarrollados si se conocen las propiedades básicas fisicoquímicas del sistema matriz solidificante-residuo.

En el presente trabajo se analizan y discuten los sistemas de inmovilización/solidificación, profundizando en los sistemas de formulaciones basadas en cemento Portland. Por último, se presentan algunos ejemplos de los resultados obtenidos del estudio de las interacciones de especies concretas de residuos y sistemas de fijación.

\begin{abstract}
SUMMARY
Immobilisation and solidification of polluting waste, introduced into the industrial sector more than 20 years ago, and throughout last 10 years is being the object of a growing interest for engineers and environment scientists, has become a remarkable standardised process for treatment and management of toxic and hazardous liquid wastes, with special to those containing toxic metals.
\end{abstract}

Experimental monitorization of the behaviour of immobilised waste by solidification and stabilisation in life time safe deposits is not possible, reason why it is essential to develop models predicting adequately the behaviour of structures that have to undergo a range of conditions simulating the environment where they are to be exposed. Such models can be developed only if the basic physical and chemical properties of the system matrix/solidifyingwaste are known.

In this work immobilisation/solidification systems are analysed stressing out the formulation systems based on Portland cement. Finally, some examples of the results obtained from the study of interaction of specific species of wastes and fixation systems are presented. 


\section{INTRODUCCIÓN}

Actualmente, las estrategias para abatir la polución tienen como objetivo fundamental la reducción de la cantidad de residuos tóxicos. Para ello, la política medioambiental propicia el reciclado de los residuos frente a su almacenamiento y el desarrollo de tecnologías limpias con baja producción de residuos. Sin embargo, un amplio espectro de la actividad humana que comprende actividades tales como la minería, la metalurgia extractiva o la rehabilitación de primitivos emplazamientos industriales, produce residuos que requieren tratamiento. Además, las modernas tecnologías de los nuevos materiales, producen nuevas corrientes de residuos. Por ejemplo, mientras que el arsénico ha sido eliminado de los materiales de decoración, se ha convertido en imprescindible en la industria de los semiconductores. Por lo tanto, no es de extrañar, que los procesos de estabilización/ solidificación, con el respaldo de la legislación vigente que impone su uso en la gestión de muchos efluentes residuales, se haya convertido en un proceso estandarizado único para el tratamiento y almacenamiento de residuos peligrosos líquidos (1) (2).

Vendedores y usuarios sólo deben probar que el producto o sus componentes químicos cumplen ciertos requisitos legales de estabilidad física o lixiviación de constituyentes tóxicos. Aunque esto ha proporcionado una base de datos que ayuda en la predicción de la estabilidad del almacenamiento a largo plazo, la falta de una información básica acerca de la química de los sistemas de estabilización/solidificación y su interacción con los residuos, no proporciona una base científica sólida para la predicción de la estabilidad o para el desarrollo de sistemas más eficaces. Los mecanismos de fijación e inmovilización y la descripción de la cinética que gobierna los procesos de lixiviación, sólo están, recientemente, empezando a ser elucidados (3) (4).

\section{PROCESOS DE INMOVILIZACIÓN/ SOLIDIFICACIÓN}

El término "inmovilización" se refiere a aquellas técnicas que reducen el riesgo potencial de un residuo al convertir sus contaminantes en sus formas menos solubles, móviles o tóxicas. La naturaleza física o las características de manejo no cambian necesariamente con la estabilización.

"Solidificación" engloba aquellos procesos desarrollados para encapsular el residuo en un sólido monolítico de alta integridad estructural. La encapsulación puede ser en finas partículas de residuo (microencapsulación ) o en un gran bloque o contenedor

\section{INTRODUCTION}

Nowadays, the main strategy to reduce pollution is the reduction of the amount of toxic waste. For this purpose, environmental politics encourage waste recycling as an option to storage, and the development of clean technologies with low waste production. However, many areas of the human activity, including activities such as coal and metal mining, and the rehabilitation of primitive industrial places, produce wastes that require treatment. Moreover, modern technologies that introduce new materials create new orientation for wastes. For example, while arsenic has been removed from decoration materials, it has become essential in semiconductors industry. Therefore, it is not surprising that processes of stabilisation/ solidification, with the support of the legislation in force which imposes this system in the management of most residual effluents, has become the only standardised treatment and storage process for hazardous liquid waste (1)(2).

Sellers and users must only prove that the product, or its chemical components, complies with the legal requirements of physical stability or of toxic components lixiviation. Although this fact has provided a database that helps predict long term storage stability, the lack of basic information about the chemistry of the stabilisation/solidification systems and its interaction with waste, it does not provides a strong scientific base for either the prediction of stability or the development of more efficient systems. Fixation and immobilisation systems and the description of kinetics governing lixiviation processes are starting nowadays to be explained (3)(4).

\section{IMMOBILISATION/SOLIDIFICATION PROCESSES}

The term "immobilisation" refers to those techniques reducing the potential risk of a waste by converting its pollutants into less toxic, movable or soluble forms. Physical properties or handling characteristics do not necessarily change with just stabilisation.

"Solidification" includes those processes developed with the purpose of encapsulating waste in a monolithic solid of high structural integrity. Encapsulation can be carried out into tiny waste particles (micro-encapsulation) or into big blocks or 
de residuos (macroencapsulación). La solidificación no implica necesariamente una interacción química entre los residuos y los reactivos solidificantes, pero puede ligar mecánicamente el residuo al monolito. $\mathrm{La}$ migración contaminante es restringida al decrecer drásticamente la superficie expuesta a lixiviación y/o al aislar los residuos dentro de una cápsula impenetrable.

Muchos residuos no están sujetos a tratamiento por inmovilización/solidificación, o no lo requieren. En general, los residuos no peligrosos sólidos no necesitan ningún tratamiento, y los líquidos pueden, en algún caso, requerir solidificación para facilitar su manejo y ubicación. Los residuos peligrosos no acuosos, tales como disolventes gastados, se gestionan más eficazmente por procedimientos como recuperación o incineración. Son los residuos líquidos catalogados como tóxicos y peligrosos los más adecuados para ser tratados por procedimientos de inmovilización/solidificación.

Dentro de los tratamientos de inmovilización/ solidificación se puede distinguir entre:

- Procesos Orgánicos, en los que monómeros o prepolímeros son polimerizados o enlazados tridimensionalmente mediante catalizadores o aceleradores después de ser mezclados con el residuo líquido. Entre los componentes más habituales en sus formulaciones se encuentran: urea-formaldehido, polibutadieno, poliester, epoxy, gel de acrilamina, poliolefina, sustancias bituminosas (asfalto), etc. Entre las ventajas de este tipo de procesos cabe destacar el hecho de que, al no ser específicos, son aplicables a una gran variedad de residuos, y el ser compatibles con las sustancias orgánicas. Sus principales inconvenientes son: las formulaciones basadas en disolventes son, a menudo, hidrofóbicas; son inestables en presencia de microorganismos o luz ultravioleta; son sistemas limitantes de la permeabilidad, en los que no tiene lugar una verdadera inmovilización; $y$ su alto costo.

- Procesos Inorgánicos, en los que los componentes más habituales son: el cemento Portland, cenizas volantes, cal, puzolanas, silicato sódico, etc. Entre sus ventajas figuran su bajo costo, su buena estabilidad fisica y química a largo plazo, su utilización bien documentada en una gran variedad de residuos industriales por un período superior a 10 años, la amplia disponibilidad de sus componentes, sus ingredientes químicos no tóxicos; es un proceso de fácil ejecución, el aumento de volumen es relativamente bajo, su inercia a la radiación ultravioleta, su resistencia a la biodegradación, su baja solubilidad en agua, su baja permeabilidad y sus buenas características mecánicas y estructurales. Sus waste containers (macro-encapsulation).

Solidification does not necessarily imply a chemical interaction between waste and solidifying reactants, but it can mechanically bind waste and monolith. Pollutant migration is restrained since the surface exposed to lixiviation decreases dramatically and/or waste is isolated in an impenetrable capsule.

Many residues are not subject to immobilisation/ solidification treatment, or they do not require it. Usually, non-harmful solid waste does not need any treatment, and liquid wastes sometimes require solidification to make easier handling and location. Hazardous non-aqueous waste such as used solvents, are managed in a more efficient way through recycling or incineration procedures. It is the liquid waste classified as toxic and hazardous the one that most requires an immobilisation/ solidification treatment.

Among immobilisation/solidification treatments a differentiation can be made between:

- Organic Processes, where monomers and prepolymers are polymerised or linked threedimensionally by means of catalysts or accelerators after being mixed to the liquid waste. Among the most usual compounds the formulations found are: urea-formaldehyde, polybutadiene, polyester-epoxy, acrylamid gel, bituminous substances (asphalt). It is worth pointing out some advantages of this kind of processes that, since they are not specific, they are applicable to a wide diversity of wastes and they are compatible with organic substances. The main disadvantages are: formulations based on solvents often are hydrophobic, they are unstable in presence of micro-organisms or ultraviolet light, they are permeability limiting systems with no total immobilisation, and their cost is high.

- Inorganic Processes, where the most common compounds are: Portland cement, fly ash, lime, pozzolan, sodium silicate, etc. Among the advantages: their low cost, good long term physical and chemical stability, well documented use on a broad variety of industrial waste for more than 10 years, availability of its components, no toxic chemical compounds, easiness of execution, relatively small volume increase, inertia regarding ultraviolet radiation, resistance to biodegradation, low solubility in water, low permeability and good mechanical and structural characteristics. The disadvantages are: they are often just specific for a kind of waste or a special condition, incompatible 
inconvenientes son: a menudo son específicos para un residuo y condiciones particulares, su incompatibilidad con altos contenidos de aceites $\mathrm{u}$ otros compuestos orgánicos, algunos procesos requieren grandes adiciones de agentes solidificantes.

\section{SISTEMAS BASADOS EN CEMENTO PORTLAND}

Los sistemas basados en cemento Portland fueron los primeros en ser utilizados en el campo de los residuos radioactivos en 1950. En ellos, el residuo, ya sea en forma sólida o acuosa, es introducido en la mezcla cementante, produciéndose una pasta de consistencia más o menos fluida que puede ser vertida en un molde o en un contenedor válido para un transporte seguro al almacén. La cementación de los residuos reduce el riesgo de un vértido o contaminación accidental en condiciones extremas.

El cemento Portland y la cal son representativos de una familia de materiales que tienen ventajas prácticas y conceptuales como matrices de inmovilización de residuos. Son materiales de construcción relativamente probados y con una amplia historia de uso en distintas condiciones ambientales.

Las ventajas de estos sistemas son numerosas:

-Tecnología probada, incluyendo procesado automático, si es necesario

-Materias primas baratas

-Su composición es constante para distintas fuentes o proveedores al existir normas para la comprobación de la calidad de producción

-Capacidad para incorporar modificadores de la matriz sólida (escorias, cenizas volantes, silicatos...) para mejorar la inmovilización de los residuos

-Buena durabilidad en la naturaleza

-Relativamente no tóxico, matriz no inflamable

-Tolerante a los residuos húmedos

-Proporciona inmovilización tanto física como química -Su alta alcalinidad desanima la actividad microbiológica

-Se conoce mucho a cerca de sus reacciones de fraguado y endurecimiento, y en la actualidad en torno a la fijación de metales en su seno

-Existen buenos estudios de modelización de la lixiviación de residuos inmovilizados en matrices de cemento procedentes del campo de los residuos nucleares.

Entre sus desventajas se pueden citar:

-Libera calor al endurecer

-Puede reaccionar con metales, liberando gas with high oil matter or other organic compounds, some processes require addition of big quantities of solidifying agents.

\section{SYSTEMS BASED ON PORTLAND CEMENT}

Systems based on Portland cement were used first in radioactive waste in 1950 . In these systems waste is added to the cement in solid or aqueous form resulting in a more or less fluid consistency that can be poured in a mould or a container fitted for a save transport to the storage place. Cementation of waste reduces the risk of external pollution by accidental spill.

Portland cement and lime are representative of $a$ group of materials that have practical and conceptual advantages when making matrices for waste immobilisation. Those are construction materials relatively well proved, and having good records of their use in different environments.

The advantages of these systems are many:

-Proved technology, including automatic processing, if necessary

-Inexpensive raw materials

-Constant composition independently of the different sources or suppliers, since there are standards that control the quality of production

-Capacity for incorporating modifiers of the solid matrix (slag, fly ash, silicates, etc.) to improve the waste immobilisation

-Good durability in natural surroundings

-Relatively "non toxic", non-flammable matrix

-Compatible with moist wastes

-Provides physical and chemical immobilisation

-Its alkalinity discourages microbiological

activity

-Its setting and hardening reactions are

well known, and also the fixation of metals in its body

-There are well-documented studies for modellisation of lixiviation of nuclear waste.

Disadvantages that must be considered:

-Heat release when hardening

-Gas release when reacting with metals 
-Una amplia gama de disolventes orgánicos e inorgánicos pueden inhibir y prevenir su fraguado -Se degrada en ambientes fuertemente ácidos y en algunas disoluciones salinas

\section{INMOVILIZACIÓN DE LOS METALES TÓXICOS Y PELIGROSOS}

Los metales contenidos en los residuos son los únicos constituyentes peligrosos que no pueden ser destruidos o alterados por métodos químicos o térmicos; $y$, por lo tanto, deben ser convertidos en su forma más insoluble posible, para evitar su vuelta al medio ambiente.

Actualmente, no existen alternativas, al margen de la recuperación, a la inmovilización/solidificación y no siempre es posible recuperar y reusar los valiosos metales presentes en los residuos por distintas razones. En ocasiones, no es económico o no existe la tecnología apropiada. Además, es necesario considerar que los productos recuperados pueden generar problemas de índole diversa en el mercado y que los procesos de recuperación, en sí mismos, generan residuos que aún contienen metales $\mathrm{y}$, a veces en una forma más lixiviable. Por estos motivos, es especialmente importante analizar los mecanismos químicos responsables de la inmovilización de cada metal en particular, involucrados en la interacción entre el residuo y la matriz cementante, ya que su conocimiento es la base lógica fundamental para realizar estimaciones inteligentes del comportamiento a largo plazo. A modo de ejemplo del estudio de las interacciones residuo-matriz cementante, en las secciones siguientes se presenta un resumen de los resultados obtenidos en investigaciones realizadas en el Instituto de Ciencias de la Construcción "Eduardo Torroja" (4-9) por los autores del presente trabajo.

\section{ESTUDIO DE LAS INTERACCIONES MATRIZCEMENTANTE-METALES TóxICOS}

El objetivo fundamental de las investigaciones realizadas consistía en mejorar los procedimientos de precipitación y estabilización de residuos tóxicos y peligrosos en base a la adecuada selección del tipo de cemento o agente cementante más idóneo para formar las fases más estables que garanticen un eficaz confinamiento del agente tóxico. Para ello se ha caracterizado el proceso de inmovilización y solidificación mediante la utilización de residuos sintéticos de $\mathrm{Cr}, \mathrm{Pb}$ y Cd. Los resultados obtenidos han sido:
- $A$ wide range of organic and inorganic solvents can inhibit and prevent its setting

-It undergoes degradation in very acid surroundings and in some saline solutions.

\section{IMMOBILIZATION OF TOXIC AND HAZARDOUS WASTES}

Metals contained in waste are the only hazardous constituents that cannot be destroyed or altered through chemical or thermal methods, therefore they must be transformed in their most possible insoluble form in order to avoid their return to environment.

At present, there are no alternatives, besides recovering, to immobilisation/solidification; unfortunately, for different reasons, it is not always possible to recover and re-use the valuable metals present in waste. Sometimes it is expensive or the appropriate technology does not exist. Besides, it is worth considering that recovered products can generate all kinds of problems in the market and yet recovering processes themselves also generate waste containing metals, and sometimes in a more lixiviable form. For this reason, it is most important to analyse the chemical mechanisms responsible for the immobilisation of each single metal involved in the interaction waste/cementing matrix, for the awareness is the logical base to build intelligent estimates of long term behaviour. An example of the study on interactions waste/cementing matrix, the results (4-9) obtained from the research performed by the authors at the Instituto de Ciencias de la Construcción "Eduardo Torroja" are presented in the next sections.

\section{STUDY OF THE INTERACTIONS BETWEEN CEMENTING MATRIX/TOXIC METALS}

The main aim of these researches was to improve precipitation and stabilisation procedures for toxic and hazardous waste in order to provide a selection of the better type of cement or cementing agent, to get more stable phases to assure an efficient confinement of the toxic agents. To this purpose the immobilisation and solidification process has been characterised by using synthetic waste of $\mathrm{Cr}, \mathrm{Pb}$ and $C d$. The results obtained are. 


\section{Estudio de la interacción de las fases sólidas mayoritarias del cemento con disoluciones acuosas de: $\mathrm{Cr}, \mathrm{Pb}$ y $\mathrm{Cd}$}

Las fases anhidras e hidratadas del cemento portland $\left(\mathrm{Ca}(\mathrm{OH})_{2}, \mathrm{C}_{3} \mathrm{~S}, \mathrm{C}_{3} \mathrm{~A}, \mathrm{AF}_{4}\right.$ y gel $\left.\mathrm{CSH}\right)$ fueron sintetizadas partiendo de reactivos para análisis, comprobándose la pureza del producto final mediante difracción de rayos $\mathrm{X}$. Estas fases sólidas fueron puestas en contacto con disoluciones que contenían los elementos tóxicos con el fin de estudiar la interacción entre ambos. Se analizó la composición del sobrenadante mediante absorción atómica y cromatografia iónica y, tras separar la fase sólida mediante centrifugación y/o filtración, se analizó ésta mediante difracción de rayos X y microscopía electrónica de barrido.

En el caso del $\mathrm{Cr}$ fue posible determinar que el elemento se incorporaba a la matriz sólida tanto en forma de hidróxido $\left(\mathrm{Cr}(\mathrm{OH})_{3} \cdot 3 \mathrm{H}_{2} \mathrm{O}\right)$ como formando parte de los aluminatos cálcicos hidratados, en los que el $\mathrm{Cr}(\mathrm{III})$ sustituye átomos de $\mathrm{Al}(\mathrm{III})$. Posteriormente se logró la síntesis de compuestos análogos a los aluminatos cálcicos en los que todo el $\mathrm{Al}$ se encuentra sustituido por $\mathrm{Cr}: \mathrm{Ca}_{2} \mathrm{Cr}(\mathrm{OH})_{7} \cdot 3 \mathrm{H}_{2} \mathrm{O}, \mathrm{Ca}_{2} \mathrm{Cr}_{2} \mathrm{O}_{5} \cdot 6 \mathrm{H}_{2} \mathrm{O}$ y $\mathrm{Ca}_{2} \mathrm{Cr}_{2} \mathrm{O}_{5} \cdot 8 \mathrm{H}_{2} \mathrm{O}$, así como diferentes disoluciones sólidas tales como hidrogranate sustituido por $\mathrm{Cr}$ : $3 \mathrm{CaO} \cdot\left(\mathrm{Al}_{2} \mathrm{O}_{3}, \mathrm{Cr}_{2} \mathrm{O}_{3}\right) \cdot 6 \mathrm{H}_{2} \mathrm{O}$.

En el caso del $\mathrm{Pb}$ fue posible determinar la incorporación del mismo en forma de $\left(\mathrm{Pb}(\mathrm{OH})_{2}\right)_{2} \cdot \mathrm{Pb}(\mathrm{OH})\left(\mathrm{NO}_{3}\right)$ en disoluciones saturadas de $\mathrm{Ca}(\mathrm{OH})_{2}$ y la formación de $\mathrm{PbSO}_{4}$ en disoluciones que contienen $\mathrm{CaSO}_{4}$.

El estudio de la interacción del Cd produjo como resultado más novedoso el descubrimiento de un nuevo hidróxido mixto de $\mathrm{Cd}$ y $\mathrm{Ca}$, que ya ha sido sintetizado por vía hidrotermal a partir de los óxidos de Ca y $\mathrm{Cd}$ con objeto de proceder a su caracterización estructural.

\section{Estudio en matrices de cemento}

2.1 Determinación de las matrices más adecuadas para la inmovilización de los cationes $\mathrm{Pb}, \mathrm{Cd}$ y $\mathrm{Cr}$

Con objeto de determinar el tipo de cemento más adecuado para la inmovilización de estos elementos, se procedió a la fabricación de probetas con diferentes cementos, usando como agua de amasado disoluciones de los elementos tóxicos en diferentes concentraciones. Se eligieron, como agentes cementantes, tres tipos de cemento: un cemento Portland tipo I/55 (OPC), un cemento con adición de escoria de alto horno (OPC/BFS), fabricado empleando

\section{Study of the interaction of solid major phases of the cement with $\mathrm{Cr}, \mathrm{Pb}$ and $\mathrm{Cd}$ aqueous solutions}

Anhydrous and hydrated phases of Portland cement $\left(\mathrm{Ca}(\mathrm{OH})_{2}, \mathrm{C}_{3} \mathrm{~S}, \mathrm{C}_{3} \mathrm{~A}, \mathrm{AF_{t }}\right.$ and $\mathrm{CSH}$ gel) were synthesised from commercial AParanalytical degree reactives, and the pureness of the final product was proved by means of $X$ ray diffraction analysis. These solid phases were put in contact with solutions containing the toxic elements in order to study their interaction. The composition of the liquid phase was analysed by means of atomic absorption and ionic chromatography, and once the solid phase was separated by means of centrifugation and/or filtration, it was analysed through XRD and SEM.

In the case of $\mathrm{Cr}$ it was possible to determine that the element gets incorporated to the solid matrix either as hydroxide $\left(\mathrm{Cr}(\mathrm{OH})_{3} \cdot 3 \mathrm{H}_{2} \mathrm{O}\right)$ or as part of the hydrated calcium aluminate, where the $\mathrm{Cr}(\mathrm{III})$ replaces Al(III) atoms. Later, the synthesis of compounds analogous to calcium aluminates was reached; there, all the Al has been found replaced by $\mathrm{Cr}: \mathrm{Ca} 2 \mathrm{Cr}(\mathrm{OH})_{7} \cdot 3 \mathrm{H}_{2} \mathrm{O}, \mathrm{Ca}_{2} \mathrm{Cr}_{2} \mathrm{O}_{5} \cdot 6 \mathrm{H}_{2} \mathrm{O}$ and $\mathrm{Ca}_{2} \mathrm{Cr}_{2} \mathrm{O}_{5} \cdot 8 \mathrm{H}_{2} \mathrm{O}$, same for the different solid solutions such as hydrogarnet which were replaced by $\mathrm{Cr}: 3 \mathrm{CaO} \cdot\left(\mathrm{Al}_{2} \mathrm{O}_{3}, \mathrm{Cr}_{2} \mathrm{O}_{3}\right) \cdot 6 \mathrm{H}_{2} \mathrm{O}$.

In the case of the $\mathrm{Pb}$ it was possible to determine its incorporation in the form of $\left(\mathrm{Pb}(\mathrm{OH})_{2}\right)_{2} \cdot \mathrm{Pb}(\mathrm{OH})\left(\mathrm{NO}_{3}\right)$ into $\mathrm{Ca}(\mathrm{OH})_{2}$ saturated solution, and $\mathrm{PbSO}_{4}$ formation in solutions containing $\mathrm{CaSO}_{4}$.

The study of the interaction of $C d$ resulted in the discovery in a new mixed $\mathrm{Cd}$ and $\mathrm{Ca}$ hydroxide, that has already been synthesised by hydrothermal means from $\mathrm{Ca}$ and $\mathrm{Cd}$ oxides in order to proceed to its structural characterisation.

\section{Study in cement matrices}

\subsection{Determination of the most adequate matrices} for immobilisation of $\mathrm{Pb}, \mathrm{Cd}$ and $\mathrm{Cr}$ cations

In order to determine the most adequate kind of cement to immobilise these elements, specimens were made using different cements and different concentrations of toxic elements solutions. Three kinds of cements were chosen as cementitious agents: Portland cement type I/55 (OPC), cement with blast 
un $20 \%$ del cemento Portland anterior y un $80 \%$ de escoria de alto horno, y un cemento aluminoso (HAC).

Las probetas se conservaron al 100\% de humedad relativa durante períodos de tiempo entre un día y un año, analizándose periódicamente la fase acuosa contenida en los poros, mediante diferentes técnicas analíticas, y la fase sólida mediante difracción de rayos $X$.

Los resultados del análisis de las fases acuosas extraídas de probetas contaminadas con cada uno de los elementos por separado se dan en la Figura 1. Estos resultados muestran claramente que el mejor resultado se obtiene, para todos los elementos analizados, mediante el empleo de cemento Portland con adición de escoria, si bien el cemento aluminoso ensayado muestra un buen comportamiento en las probetas contaminadas con $\mathrm{Pb}$ y Cd. Posteriormente se procedió a la realización de probetas contaminadas con una disolución que contiene todos los elementos considerados. Los resultados presentados en la furnace slag (OPC/BFS) made of $20 \%$ Portland cement and $80 \%$ blast furnace slag, and high alumina cement (HAC).

Specimens were kept at $100 \%$ relative humidity for periods lasting from one day to one year, the aqueous phase filling the pores being analysed periodically by means of different analytical techniques, and the solid phase by means of X-ray diffraction.

The results of the analysis of the aqueous phases extracted from specimens polluted separately with each one of the elements are shown in Figure 1. Results show distinctly that the best behaviour, among all elements analysed, is obtained when using Portland cement with slag addition, although the high alumina cement tested shows good behaviour in specimens polluted with $\mathrm{Pb}$ and $\mathrm{Cd}$. Later, specimens polluted with a solution containing all elements already considered were made. Results presented in
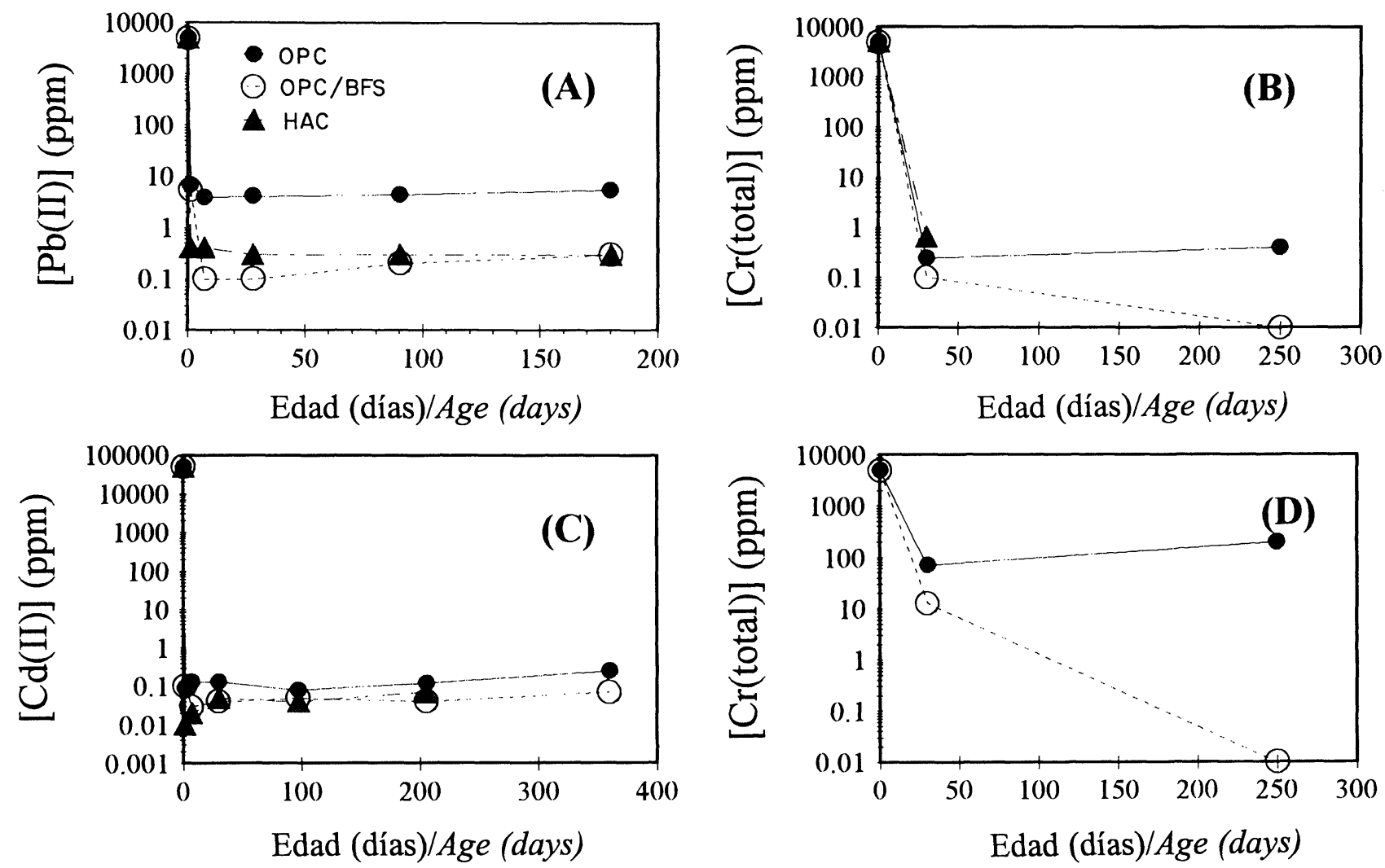

Figura 1.- Concentraciones de los diferentes cationes ensayados en la fase acuosa extraída de diferentes cementos contaminados con: $\mathrm{A}$ ) $5000 \mathrm{ppm}$ de $\mathrm{Pb}$ (II), B) 5000 ppm de Cr (III), C) 50000 ppm de Cd(II) y D) 5000 ppm de Cr (VI).

Figure 1.- Concentrations of the different cations tested in the aqueous phase extracted from different cements polluted with: A) 5000 ppm de Pb (II), B) 5000 ppm de Cr (III), C) 50000 ppm de Cd (II) y D) 5000 ppm de Cr (VI). 

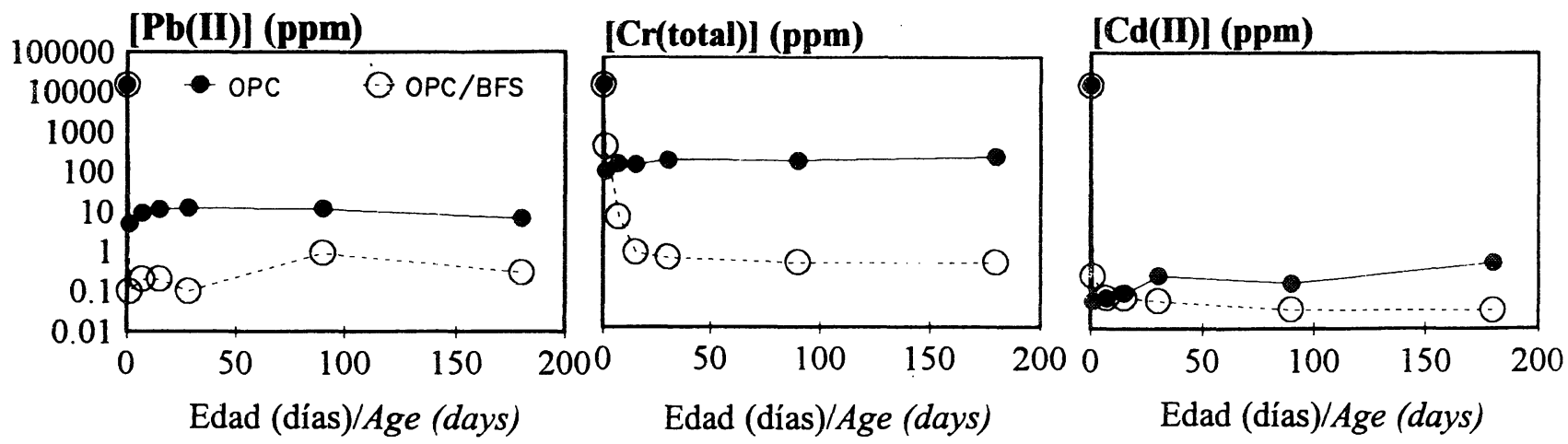

Figura 2.- Concentraciones de los diferentes cationes ensayados en la fase acuosa extraída de diferentes cementos contaminados con una solución que contiene: $15000 \mathrm{ppm}$ de $\mathrm{Pb}$ (II) $+15000 \mathrm{ppm}$ de Cd (II) $+15000 \mathrm{ppm} \mathrm{de} \mathrm{Cr}$ (III) $+5000 \mathrm{ppm} \mathrm{de} \mathrm{Cr}$ (VI)

Figure 2.- Concentrations of the different cations tested in the aqueous phase extracted from different cements polluted with a solution containing: 15000 ppm de Pb (II) +15000 ppm de Cd (II) +15000 ppm de Cr (III) +5000 ppm de Cr (VI).

Figura 2 muestran que el cemento, de nuevo, con adición de escoria de alto horno, presenta una capacidad de inmovilización mayor que el cemento Portland sin adiciones. Además, las concentraciones de los diferentes elementos en la fase acuosa no se ven alteradas respecto a las medidas en las probetas contaminadas con uno solo de los contaminantes, salvo en el caso del $\mathrm{Cr}$, en donde son sensiblemente más altas pero muy por debajo de los valores medidos en el cemento Portland sin adición de escoria.

Las medidas de especiación de $\mathrm{Cr}$ (III) y Cr (VI) han revelado que en el cemento con adición de escoria, debido al carácter reductor de ésta, se produce una reducción del $\mathrm{Cr}$ (VI) al estado de oxidación $3+$, que, como se ha comprobado en el apartado 1, precipita en forma de compuestos de baja solubilidad.

Los estudios de difracción de rayos-X llevados a cabo sobre la fase sólida de las probetas contaminadas no revelan la presencia de ningún compuesto cristalino diferente de los habitualmente presentes en los cementos estudiados, salvo en el caso de las probetas contaminadas con $\mathrm{Cd}$, donde se han detectado los picos correspondientes al hidróxido mixto $(\mathrm{Ca}, \mathrm{Cd})(\mathrm{OH})_{2}$, cuya estructura cristalina y estequiometría precisa se está actualmente determinando.

\subsection{Durabilidad de las matrices que contienen los elementos tóxicos}

A partir de los estudios del apartado 2.1. se ha elegido la matriz de cemento Portland con adición del $80 \%$ de escoria de alto horno para realizar los estudios de durabilidad. Además, se han realizado los mismos estudios en matrices de cemento Portland sin adición.
Figure 2 show again that the new cement with blast furnace slag shows a bigger capacity for immobilisation than Portland cement without additions. Moreover, the concentrations in different elements in aqueous phase are not altered with respect to the measures in specimens polluted with a single one of the pollutants, except for the case of $\mathrm{Cr}$ where they are slightly higher but much lower than mean values given by Portland cement with no slag addition.

Speciation measures of $\mathrm{Cr}$ (III) and $\mathrm{Cr}(\mathrm{VI})$ revealed that in slag added cement, because of the reductive characteristic of slag, a reduction of the $\mathrm{Cr}(\mathrm{VI})$ to the $3+$ oxidation state happens, which precipitates in the form of low solubility compounds, as proved in previous section 1.

Studies through XRD carried on the solid phase of the polluted specimens do not reveal any presence of crystalline compounds different from those usually present in the cements already investigated, except for the case of specimens polluted with $C d$, where reflections corresponding to mixed hydroxide $(\mathrm{Ca}, \mathrm{Cd})(\mathrm{OH})_{2}$ whose crystalline structure and precise stoichiometry has been determined.

\subsection{Durability of matrices containing toxic elements}

Taking as a base the studies described in section 2.1., a Portland cement matrix with addition of $80 \%$ blast furnace slag has been chosen to carry out the research on durability. Besides, same studies have been carried out on Portland cement matrices but without additive. 
Los estudios de durabilidad se han dividido en dos tipos:

- 2.2.a. Estudio de durabilidad frente a diferentes medios agresivos

- 2.2.b. Estudio del proceso de carbonatación

2.2.a. Durabilidad de las matrices que contienen los metales tóxicos frente a la acción de diferentes medios agresivos

Para realizar este ensayo se eligieron dos medios potencialmente agresivos: una disolución salina $0,45 \mathrm{M}$

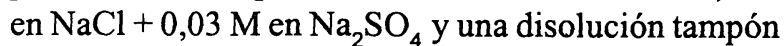
acético/acetato de $\mathrm{pH} 4,5$. Paralelamente se llevó a cabo un ensayo en agua destilada para usarlo como referencia. En todos los ensayos la relación Superficie de Cemento/ Volumen de agresivo fue de $0,195 \mathrm{~cm}^{-1}$ y la relación Masa de Cemento/Volumen de agresivo de 0,100 gr/ml.

La disolución salina contiene una concentración de aniones $\mathrm{Cl}^{-}$y $\mathrm{SO}_{4}{ }^{2-}$ equivalente a la del agua de mar, mientras que la disolución ácida se escogió porque, aun siendo éste el medio empleado en los ensayos normalizados de lixiviación de metales pesados, es un medio en el que el comportamiento del cemento ha sido muy poco estudiado.

La durabilidad de las pastas de cemento hidratadas durante 21 días, con y sin presencia de elementos tóxicos, fue estudiada por medio del ensayo de Köch y Steinegger durante 90 días a $20 \pm 1^{\circ} \mathrm{C}$. Los cambios microestructurales de las pastas fueron evaluados por difracción de rayos-X, medida de la porosidad mediante porosímetro de mercurio y observación por microscopia electrónica. Asimismo, se analizó la fase acuosa extraída de las probetas después de sacarlas de los medios agresivos.

Como resultado de estos ensayos fue posible establecer que el cemento Portland y los cementos con adición de escorias de alto horno son matrices durables en un medio salino similar al agua de mar, pero sufren un ataque ácido con formación de una capa porosa de degradación en el medio ácido estudiado. Este ataque ácido es mayor para un cemento con adición de escoria.

Por otra parte, la descomposición y degradación de los cementos Portland y cemento con adición de escorias, conduce a la disolución de los elementos tóxicos, en especial cuando éstos están precipitados como hidróxidos tal y como ocurre en el caso del cemento Portland. La precipitación de los metales en forma de sulfuros que tiene lugar en presencia de escorias hace estas matrices mejores para la inmovilización de $\mathrm{Pb}$ y Cd cuando el residuo estabilizado es almacenado en medios ácidos, aunque debe tenerse en cuenta que estas matrices sufren un severo ataque en medio ácido.
Research on durability has been split into:

- 2.2.a. Study on durability of samples submitted to different aggressive conditions.

- 2.2.b. Study of the carbonation process.

2.2.a. Durability of matrices containing toxic metals submitted to different aggressive conditions

Potentially aggressive environments were chosen to carry out this test: a saline solution $0.45 \mathrm{M}$ in $\mathrm{NaCl}$ $+0.03 \mathrm{M}_{\text {in }} \mathrm{Na}_{2} \mathrm{SO}_{4}$ and an acetic/acetate buffer solution of $4.5 \mathrm{Ph}$. At the same time a test was carried out in distilled water for its use as reference. In all tests Cement Surface/Aggressive Volume was 0.195 $\mathrm{cm}^{-1}$, and Cement Mass/Aggressive Volume ratio was $0.100 \mathrm{gr} / \mathrm{ml}$.

Saline solution contains a $\mathrm{Cl}^{-}$and $\mathrm{SO}_{4}^{2-}$ anion concentration equivalent to sea water; the acid solution was chosen because, even being the one used in standardised tests of hard metals lixiviation, cement behaviour in this element has been scarcely studied.

Durability of cement pastes hydrated during 21 days with or without the presence of toxic elements was studied through Köch and Steinegger test during 90 days at $20^{\circ} \mathrm{C} \pm 1{ }^{\circ} \mathrm{C}$. Microstructural changes in pastes were evaluated by $X$-ray diffraction, porosity measurement by mercury intrusion porosimetry and observation through scanning electron microscopy. Moreover, aqueous phase extracted from specimens after taking them out of aggressive environment was analysed.

From these tests it has been possible to establish that Portland cement and cements with slag addition are durable components for matrices in a saline environment similar to sea water, but they have to endure an acid attack which provokes the formation of a degradation porous layer in the studied acid environment. This attack is stronger in cement with slag additions.

In the other hand, decomposition and degradation of Portland cements and cements with slag addition drive to the dissolution of toxic elements, specially when these elements are precipitated as hydroxides, as it happens in the instance of Portland cement. Precipitation of metals in the form of sulphurs, that takes place when slag is present, makes these matrices better fitted for $\mathrm{Pb}$ and $\mathrm{Cd}$ immobilisation when the stabilised waste is stored within acid environment. 
Los resultados obtenidos del análisis de lixiviados y de la fase acuosa muestran un excelente comportamiento de ambas matrices (Cemento Portland y cemento Portland con adición de escoria) en agua destilada y en el medio salino estudiados. En ambos casos, la concentración de los elementos tóxicos estudiados en el lixiviado se mantiene por debajo de los límites de detección de la técnica empleada $(0,01 \mathrm{ppm}$ para el Cd y 0,1 ppm para el $\mathrm{Pb}$ ).

En el medio ácido se produce una lixiviación mucho más importante de metales tóxicos, como puede observarse en la Figura 3. Sin embargo, aun en estas condiciones, el $94 \%$ del $\mathrm{Pb}$ (II) añadido a las probetas de cemento Portland y el $86 \%$ del $\mathrm{Pb}$ (II) añadido al cemento de escorias permanecía aún formando parte de la fase sólida, a pesar de que la integridad estructural se hallaba sensiblemente disminuida.

\section{2.b. Estudio del proceso de carbonatación}

Por carbonatación se entiende el proceso natural por el que las fases de la pasta de cemento reaccionan con el $\mathrm{CO}_{2}$ atmosférico para dar como producto final carbonato de calcio y $\mathrm{SiO}_{2}$. Para estudiar el efecto de este proceso sobre la capacidad de inmovilización de los diferentes materiales ensayados se procedió a realizar un ensayo acelerado empleando cámaras en las que se mantiene una elevada concentración de $\mathrm{CO}_{2} \mathrm{y}$ una humedad relativa en torno al 55-65\% que se ha mostrado como la más favorable para el proceso.

Los estudios realizados con los elementos tóxicos por separados muestran un comportamiento diferente de cada uno de los elementos considerados.
Results from analyses of leached elements and of the aqueous phase show an excellent behaviour in both matrices (Portland cement and Portland cement with slag addition) immersed in distilled water and in the studied saline environment. In both cases, the concentration of toxic elements leached states under the detection limits of the technique used $(0.01 \mathrm{ppm}$ for $\mathrm{Cd}$ and $0.1 \mathrm{ppm}$ for $\mathrm{Pb}$ ).

In acid environment there is a much more important leaching of toxic metals, as Figure 3 indicates. However, even in these conditions, $94 \%$ of $\mathrm{Pb}(\mathrm{II})$ added to Portland cement specimens, and $86 \%$ of $\mathrm{Pb}(\mathrm{II})$ added to slag cement still remained as components of the solid phase, although the structural integrity showed an appreciable decrease.

\section{2.b. Study of the carbonation process.}

Carbonation involves a natural process that makes the phases of the cement paste to react with atmospheric $\mathrm{CO}_{2}$ that gives as final product calcium carbonate and $\mathrm{SiO}_{2}$. The effect of this process on the immobilisation capacity of the different materials tested was studied through an accelerated test in chambers that kept a high concentration of $\mathrm{CO}_{2}$, and $55-65 \%$ relative humidity which is the most suitable for this process.

Studies carried out testing the toxic elements separately show a different behaviour for each one of the elements considered.
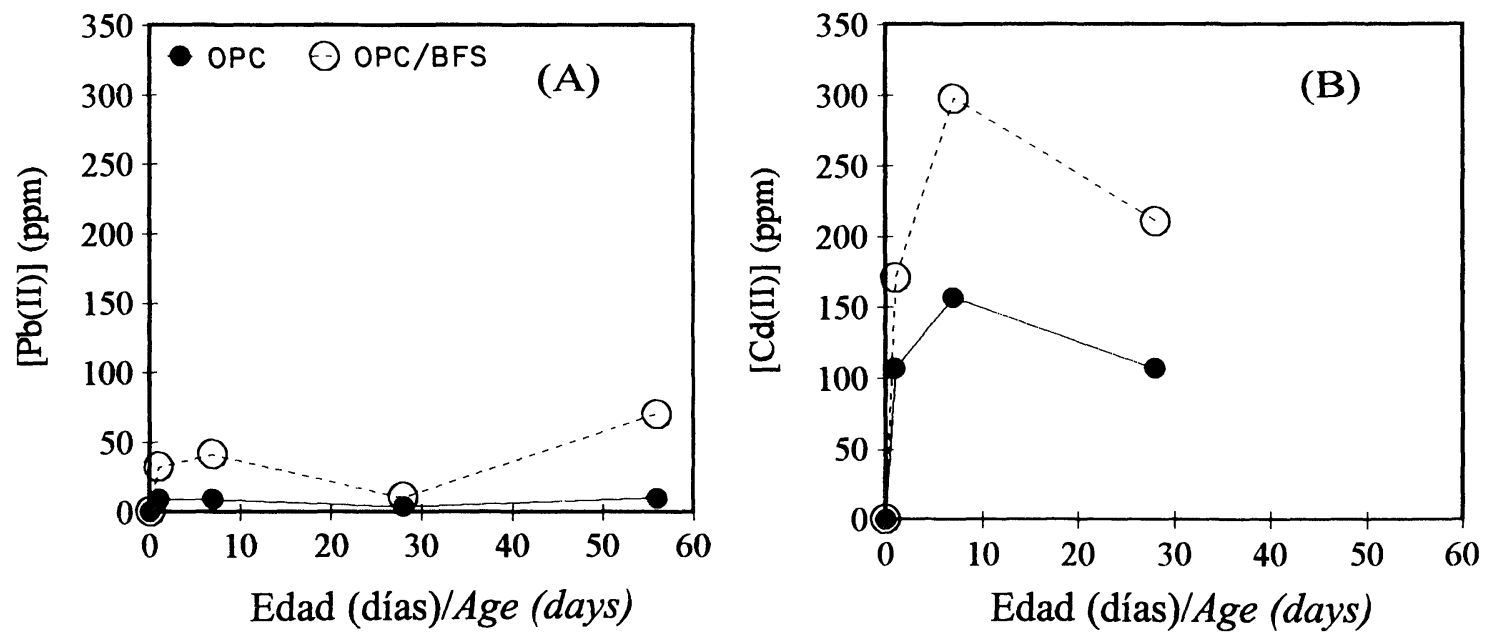

Figura 3.- Concentración de elementos tóxicos medidos en el lixiviado en medio ácido $(\mathrm{pH}=4,5)$. A) Probetas contaminadas con $\mathrm{Pb}$. $\mathrm{B}) \mathrm{Probetas}$ contaminadas con Cd.

Figure 3.- Concentration of toxic elements leached states in acid environment $(p H=4.5)$. A) Specimens polluted with Pb. B) Specimens polluted with Cd. 
En los estudios llevados a cabo con probetas contaminadas con $\mathrm{Cr}$ en sus dos estados de oxidación las probetas carbonatadas presentaban una concentración más elevada de $\mathrm{Cr}$ en fase acuosa, manteniéndose, sin embargo, una mejor inmovilización en las probetas realizadas con cemento Portland con adición de escoria.

En el caso de las probetas contaminadas con $\mathrm{Pb}$ (II), la carbonatación de las probetas hace descender 10 veces la concentración de $\mathrm{Pb}$ en la fase acuosa extraída del cemento Portland, mientras que la concentración medida en la fase acuosa del cemento con adición de escoria no parece alterarse durante la carbonatación.

En las probetas contaminadas con Cd (II), los ensayos realizados muestran una disminución de la concentración medida en la fase acuosa del cemento Portland tras 90 días de permanencia en la cámara de carbonatación, mientras que no se observan variaciones en las probetas realizadas con cemento Portland con adición de escorias (Tabla 1).

Los ensayos realizados con probetas contaminadas con los tres elementos tóxicos muestran ligeras variaciones respecto a la de los cementos contaminados con un sólo elemento. Mientras que el $\mathrm{Pb}$ se comporta de manera similar a como lo hace en ausencia de interacción con los demás elementos, el $\mathrm{Cd}$ se ve afectado de modo claramente negativo y, en el caso del $\mathrm{Cr}$, los efectos negativos de la carbonatación desaparecen e incluso se invierten en las probetas fabricadas con adición de escoria de alto horno (Tabla 2).
In the studies carried out on specimens polluted with $\mathrm{Cr}$ in the two stages of oxidation, carbonated specimens show a higher concentration of $\mathrm{Cr}$ in aqueous phase, but there is a better immobilisation in specimens made of Portland cement with slag addition.

In the case of specimens polluted with $\mathrm{Pb}(I I)$, the carbonation makes to lower 10 times the $\mathrm{Pb}$ concentration in the aqueous phase of cement Portland, while the concentration measured in cement Portland with addition of slag does not seem to bear any change during carbonation.

Tests on specimens polluted with Cd(II) showed a decrease of the concentration. The measure was taken in aqueous phase of Portland cement after 90 days in carbonation chamber, while no variations were observed in specimens made with Portland cement with slag addition (Table 1).

Tests carried out in specimens polluted with the three toxic elements $(\mathrm{Pb}+\mathrm{Cd}+\mathrm{Cr})$ show slight variations with respect to the cements polluted with one single element. While $P b$ behaves in a similar way as it does when deprived of other elements interaction, the Cd is affected negatively, and in the case of $\mathrm{Cr}$ the negative effects of carbonation disappear and even reverse as in the case of specimens made with addition of blast furnace slag (Table 2).

\section{TABLA | (TABLE |)}

Medidas de concentración de elementos tóxicos en probetas contaminadas con un sólo elemento tras 90 días de curado en aire al $100 \%$ de humedad relativa (sin carbonatar) o tras 90 días en cámara con atmósfera rica en $\mathrm{CO}_{2}$ al $60 \%$ de humedad relativa

Measures of concentrations of toxic elements in specimens polluted with one single element $(\mathrm{Pb}, \mathrm{Cd}$ or $\mathrm{Cr}$ ) after being cured during 90 days at 100\% relative humidity (without carbonation) or after 90 days in chamber with an environment rich in $\mathrm{CO}_{2}$ and $60 \%$ relative humidity)

\begin{tabular}{|c|c|c|c|c|c|}
\hline \multirow[b]{2}{*}{$\begin{array}{l}\text { Elemento } \\
\text { analizado } \\
\text { (Analysed } \\
\text { element) }\end{array}$} & \multirow[b]{2}{*}{$\begin{array}{l}\text { Contaminante } \\
\text { añadido } \\
\text { (Spiked solution) }\end{array}$} & \multicolumn{2}{|c|}{$\begin{array}{l}\text { Cemento Portland } \\
\text { (Portland Cement) } \\
\text { OPC }\end{array}$} & \multicolumn{2}{|c|}{$\begin{array}{c}\text { Cemento de Escorias } \\
\text { (Slag Cement) } \\
\text { OPC/BFS }\end{array}$} \\
\hline & & $\begin{array}{l}\text { Sin } \\
\text { carbonatar } \\
\quad \text { (Non } \\
\text { carbonated) }\end{array}$ & $\begin{array}{l}\text { Carbonatadas } \\
\text { (Carbonated) }\end{array}$ & $\begin{array}{l}\text { Sin } \\
\text { carbonatar } \\
\text { (Non } \\
\text { carbonated) }\end{array}$ & $\begin{array}{l}\text { Carbona- } \\
\text { tadas } \\
\text { (Carbonated/ }\end{array}$ \\
\hline$[\mathrm{Pb}(I I)]$ & 5.000 ppm $\mathrm{Pb}(1 \mathrm{I})$ & $4,9 \mathrm{ppm}$ & $0,5 \mathrm{ppm}$ & $0,2 \mathrm{ppm}$ & $0,1 \mathrm{ppm}$ \\
\hline$[\mathrm{Cd}(11]$ & $5.000 \mathrm{ppm} \mathrm{Cd}(11)$ & $0,1 \mathrm{ppm}$ & $0,04 \mathrm{ppm}$ & $0,05 \mathrm{ppm}$ & $0,04 \mathrm{ppm}$ \\
\hline$\left[\mathrm{Cr}_{\text {total }}\right]$ & $5.000 \mathrm{ppm} \mathrm{Cr}(\mathrm{III})$ & $0,5 \mathrm{ppm}$ & $6,06 \mathrm{ppm}$ & $0,01 \mathrm{ppm}$ & $0,13 \mathrm{ppm}$ \\
\hline$\left[\mathrm{Cr}_{\text {total }}\right]$ & $5.000 \mathrm{ppm}$ Cr(VI) & 203 ppm & $547 \mathrm{ppm}$ & $0,01 \mathrm{ppm}$ & $1,10 \mathrm{ppm}$ \\
\hline
\end{tabular}


Concentración de los elementos tóxicos en la fase acuosa de probetas contaminadas con una mezcla de elementos contaminantes tras 90 días de curado en aire al $100 \%$ de humedad relativa (sin carbonatar) o tras 90 días en cámara de atmósfera rica en $\mathrm{CO}_{2}$ al $60 \%$ de humedad relativa (Concentracion of toxic elements in aqueous phase in specimens polluted with a mixture of contaminating elements lafter 90 days kept at $100 \%$ relative humidity (without carbonation) or after 90 days in chamber with an environment atmosphere rich in $\mathrm{CO}_{2}$, at $60 \%$ relative humidity)

\begin{tabular}{|c|c|c|c|c|c|}
\hline \multirow[b]{2}{*}{$\begin{array}{l}\text { Elemento } \\
\text { analizado } \\
\text { (Analysed } \\
\text { element) }\end{array}$} & \multirow[b]{2}{*}{$\begin{array}{l}\text { Contaminante añadido } \\
\text { (Spiked solution) }\end{array}$} & \multicolumn{2}{|c|}{$\begin{array}{l}\text { Cemento Portland } \\
\text { (Portland Cement) } \\
\text { OPC }\end{array}$} & \multicolumn{2}{|c|}{$\begin{array}{c}\text { Cemento de Escorias } \\
\text { (Slag Cement) } \\
\text { OPC/BFS }\end{array}$} \\
\hline & & $\begin{array}{l}\text { Sin } \\
\text { carbonatar } \\
\text { (Non } \\
\text { carbonated) }\end{array}$ & $\begin{array}{l}\text { Carbonatadas } \\
\text { (Carbonated) }\end{array}$ & $\begin{array}{l}\text { Sin } \\
\text { carbonatar } \\
\text { (Non } \\
\text { carbonated) }\end{array}$ & $\begin{array}{c}\text { Carbona- } \\
\text { tadas } \\
\text { (Carbonated) }\end{array}$ \\
\hline$[\mathrm{Pb}(\mathrm{II})]$ & \multirow{3}{*}{ 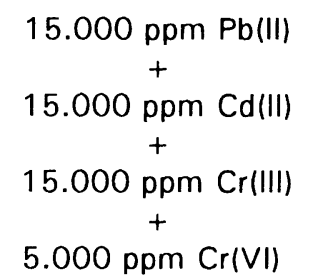 } & $11,7 \mathrm{ppm}$ & $0,4 \mathrm{ppm}$ & 0,9 ppm & $1,0 \mathrm{ppm}$ \\
\hline$[\mathrm{Cd}(I I)]$ & & $0,14 \mathrm{ppm}$ & $0,7 \mathrm{ppm}$ & $0,03 \mathrm{ppm}$ & $0,17 \mathrm{ppm}$ \\
\hline$\left[\mathrm{Cr}_{\text {total }}\right]$ & & 209 ppm & 263 ppm & $0,46 \mathrm{ppm}$ & $0,12 \mathrm{ppm}$ \\
\hline
\end{tabular}

Cabe concluir que, a pesar de las variaciones en la concentración del elemento tóxico que tienen lugar durante el proceso de carbonatación, éstas se mantienen en niveles muy bajos, salvo para el caso del Cr en el cemento portland, para el que el comportamiento ya era malo, incluso en ausencia de carbonatación.

\section{AGRADECIMIENTOS}

Los autores agradecen a la CICYT la ayuda económica recibida (proyectos AMB93-0022 y AMB96-0451) y a $\mathrm{D}^{\mathrm{a}}$ Julia Mallart la traducción al inglés.
From the results obtained it is possible to conclude that, in spite of the variations in the toxic element concentration that take place during the carbonation process, these concentrations keep in very low levels, except for the case of $\mathrm{Cr}$ in Portland cement, which already had a bad behaviour even in the absence of carbonation.

\section{ACKNOWLEDGEMENTS}

The authors gratefully acknowledge the assistance of CICYT through the financial support (projects AMB93-0022 and AMB96-0451) and $D^{a}$ Julia Mallart for english translation.

\section{BIBLIOGRAFÍA}

(1) M.J. CULLINANE, Jr., L.W. JONES y P.G. MALONE: Handbook for Stabilization/Solidification of Hazardous Waste, U.S. environmental Protection Agency, Cincinnati, Ohio(1986).

(2) J.R. CONNER: Chemical Fixation and Solidification of Hazardous Wastes, Van Nostrand Reinhold, New York(1990).

(3) D.E. MACPHEE y F.P. GLASSER: Immobilization Science of Cement Systems, Mat. Res. Soc. Bull. XVIII, pp. 66-71 (1993).

(4) A. KINDNESS, A. MACÍAS y F.P. GLASSER: Immobilization of Chromium in Cement Matrices, Waste Management, Vol. 14(1), pp. 3-11 (1994).

(5) A. MACÍAS, A. KINDNESS y F.P. GLASSER: Impact of Carbon Dioxide on the Immobilization Potential of Cemented Wastes: Chromium, Cem. Conc. Res., Vol. 27(2),pp. 215-225 (1997).
(6) J.M. DÍEZ, J. MADRID y A. MACÍAS: Characterization of Cement-Stabilized Cd Wastes, Cem. Conc. Res., Vol. 27(4), pp. 479-485(1997).

(7) S. GOÑI, A. MACÍAS, J. MADRID y J.M. DÍEZ: Characterization of a New Ca-Cd Hydroxide Hydrothermally Synthesized and its Implications for Cement Isolation of Cd, J. Mater. Res., Vol. 13(1), pp. 16-21 (1998).

(8) J. MADRID, J.M. DÍEZ, S. GOÑI y A. MACÍAS: Durability of Cement Matrices Used for Stabilization of Hazardous Wastes, Fourth CANMET/ACI International Conference on Durability of Concrete, Sydney, Australia, agosto 17-22(1997).

(9) A. MACÍAS, S. GOÑI, J. MADRID, J.M. DÍEZ y E. DEL CASTILLO: Potential of Blast Furnace Slag to Immobilize Toxic Wastes, Sixth CANMET/ACI International Conference on Fly Ash, Silica Fume, Slag and Natural Pozzolans in Concrete, Bangkok, Thailand, mayo 31 -junio 5 (1998). 